\title{
Glacier anomaly over the western Kunlun Mountains, Northwestern Tibetan Plateau, since the 1970s
}

\author{
YETANG WANG, ${ }^{1}$ SHUGUI HOU, ${ }^{2}$ BAOJUAN HUAI, ${ }^{1}$ WENLING AN, ${ }^{3}$ \\ HONGXI PANG, ${ }^{2}$ YAPING LIU ${ }^{4}$ \\ ${ }^{1}$ College of Geography and Environment, Shandong Normal University, Jinan 250014, China \\ ${ }^{2}$ Key Laboratory of Coast and Island Development of Ministry of Education, School of Geographic and Oceanographic \\ Sciences, Nanjing University, Nanjing 210093, China \\ ${ }^{3}$ Institute of Geology and Geophysics, Chinese Academy of Sciences, Beijing 100029, China \\ ${ }^{4}$ State Key Laboratory of Cryospheric Sciences, Cold and Arid Regions Environmental and Engineering Research Institute, \\ Chinese Academy of Sciences, Lanzhou 730000, China \\ Correspondence: Y.Wang <wangyetang@163.com>; S. Hou <shugui@nju.edu.cn>
}

\begin{abstract}
Western Kunlun Mountain (WKM) glaciers show balanced or even slightly positive mass budgets in the early 21st century, and this is anomalous in a global context of glacier reduction. However, it is unknown whether the stability prevails at longer time scales because mass budgets have been unavailable before 2000. Here topographical maps, Shuttle Radar Topography Mission and Landsat data are used to examine the area and surface elevation changes of glaciers on the WKM since the 1970s. Heterogeneous glacier behaviors are observed not only in the changes of length and area, but also in the spatial distribution of surface elevation changes. However, on average, glacier area and elevation changes are not significant. Glaciers reduce in the area by $0.07 \pm 0.1 \% \mathrm{a}^{-1}$ from the 1970s to 2016. Averaged glacier mass loss is $-0.06 \pm 0.13 \mathrm{~m}$ w.e. $\mathrm{a}^{-1}$ from the 1970 s to 1999 . These findings show that the WKM glacier anomaly extends back at least to the 1970s.
\end{abstract}

KEYWORDS: glacier changes, Tibetan plateau, western Kunlun Mountains

\section{INTRODUCTION}

In recent decades, much attention has been paid to global glacier reduction and its consequences for sea-level rise and the mountain ecosystem (e.g. Immerzeel and others, 2010; Gardelle and others, 2012a). Glaciers located in the western Kunlun Mountains (WKM), Karakoram, Pamirs and Himalaya represent the largest ice masses outside of the polar regions (Smiraglia and others, 2007). They are the headwaters of many prominent rivers such as the Indus, Ganges and Brahmaputra, and play an important role as the water towers of Asia (Yao and others, 2012). Glaciers in the WKM, Pamirs and Karakoram have become a focus of public and scientific debate due to their unusual behavior (e.g. Hewitt, 2005; Gardner and others, 2013; Kääb and others, 2015). In contrast to worldwide glacier reduction, their overall areas present no significant changes, with some glaciers advancing or surging in recent decades (e.g. Copland and others, 2011; Bhambri and others, 2013). Additionally, their mass is stable or even growing in the early 21st century (e.g. Bolch and others, 2012; Ke and others, 2015; Zhang and others, 2016).

In contrast, glaciers in the Himalaya are reported to be losing mass rapidly during the same period (e.g. Bolch and others, 2011; Kääb and others, 2015; Maurer and others, 2016). These contrasting glacier changes may result from regional variations in climatic change (Maussion and others, 2014; Wiltshire, 2014). To determine if recent variations in glaciers are representative for longer time periods, glacier mass budgets have been extended to the 1970s over the middle and eastern Himalaya (e.g. Maurer and others, 2016; Ragettli and others, 2016), eastern Pamirs (Holzer and others, 2015; Zhang and others, 2016) and central Karakoram (Bolch and others, 2017). They reveal that the stability of glaciers over the Karakoram and Pamirs is probably not limited to the past 15 years, but extends back at least to several-decade time span. Very recent research (Zhou and others, 2018) indicates that WKM glaciers have been stable prior to 2000, and are part of a larger regional anomaly that includes the Pamirs and Karakoram (Kääb and others, 2015).

Based on the first and second Chinese Glacier Inventories (CGI) and Landsat images, some attempts have been made to determine changes in glacier extent over the WKM since 1970 (e.g. Shangguan and others, 2007; Ji and others, 2013; Wei and others, 2014; Bao and others, 2015). Shangguan and others, (2007) found a slight area increase from 1991 to 2001, and no significant change during the period 1970-2001. Ji and others (2013) reported slightly positive conditions of six typical glaciers from 1991 to 2009. Bao and others (2015) indicated only $-3.4 \pm 3.1 \%$ reduction in glacier area over WKM for the 1970-2010 period. These results seem to suggest that WKM glaciers have been in balance or changing insignificantly during the last several decades. To further confirm this, there is still a need to examine changes in the glacier mass budget before 2000. Thus, the major objective of this study is to quantify the changes in mass budget over WKM glaciers before 2000 by means of geodetic measurements to fill a knowledge gap, and also to give possible climatic consideration for the glacier changes in the WKM.

\section{STUDY AREA}

WKM, located on the northwestern Tibetan Plateau (Fig. 1), is one of the most extensively glacierized regions in China (Shi and others, 2008). Morphologically, the WKM contain 


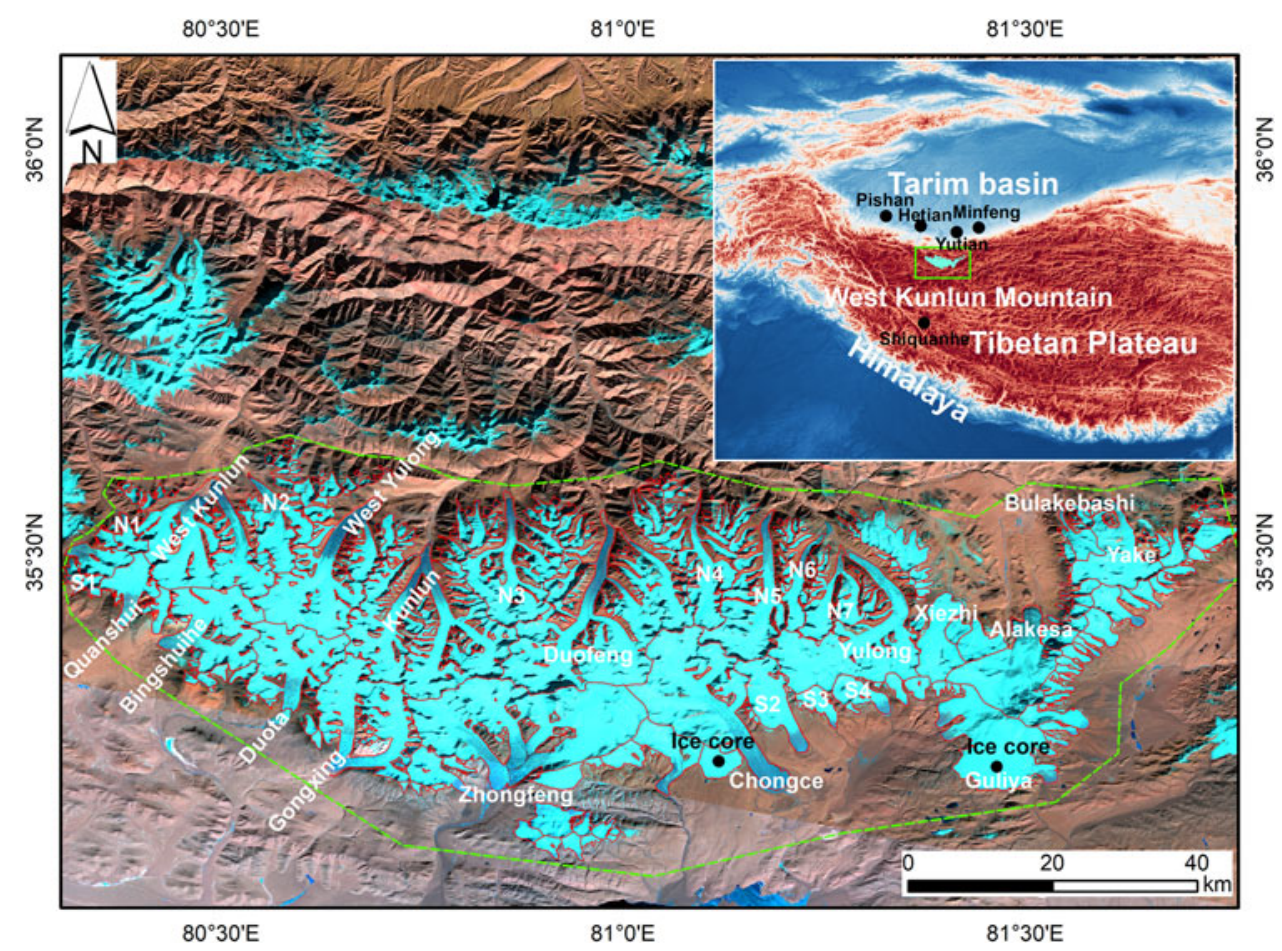

Fig. 1. Western Kunlun Mountains (WKM) on Landsat 8 OLI image false-color composite (band 7, 5, 4 for R, G, B) acquired in September 2016. Inset indicates the locations of meteorological stations, WKM and Tibetan Plateau. Glacier outlines are derived from the topographical maps generated in 1968-71. The names of well-known glaciers are presented, and the unnamed glaciers in the north and south slopes have identifiers prefixed by $N$ or $S$, respectively.

cirque glaciers, valley glaciers and ice caps, nine of which have an extent of $>100 \mathrm{~km}^{2}$. Over the rugged northern slopes, valley glaciers are dominant, while ice caps are mainly distributed over the southern slopes. Among them, Guliya Ice Cap is the largest ice cap in mainland Asia covering an area of $>370 \mathrm{~km}^{2}$. These glaciers are situated in an extremely cold and dry continental climate (Zhou and others, 2014) and are almost debris free $(<3 \%$ debriscovered area) (Scherler and others, 2011). End-of-summer transient snowlines range from 5900 to $6100 \mathrm{~m}$ a.s.I and the average equilibrium line (ELA) elevation is $5930 \mathrm{~m}$ a.s.l (Zhang and Jiao, 1987). Primarily controlled by mid-latitude westerlies, the climate of WKM is cold and semi-arid, with most precipitation occurring between May and September (Zhang and others, 1989). Near the ELA, annual mean air temperature and precipitation reach $\sim-13.9^{\circ} \mathrm{C}$ and 300 $\mathrm{mm}$, respectively (Zhang and others, 1989). The glaciers provide seasonal to long-term downstream freshwater supply and also act as invaluable indicators of climate changes (e.g. Vaughan and others, 2013; An and others, 2016).

\section{DATA AND METHODS}

\subsection{Data}

\subsubsection{DEM70}

We collected seven topographic maps at a scale of 1:100 000, which were generated from 1: 60000 aerial stereo pairs acquired during $1968-71$ by the Chinese Military Geodetic Service (CMGS). They are referenced to the Beijing Geodetic Coordinate System 1954 (BJ54) geoid and the Yellow Sea 1956 datum (the averaged sea level at the Qingdao Tidal Observatory in 1956). The contour and points of elevation were digitized from these topographic maps by the State Bureau of Surveying and Mapping of China and reprojected to the Xian Geodetic Coordinate System 1980 (GDZ80) geoid using the Yellow Sea 1985 datum. The digital contour and points were then used to construct a triangulated irregular network (TIN) and the TIN was interpolated to an $\sim 50 \mathrm{~m}$ resolution DEM called DEM70.

According to General Administration of Quality Supervision Inspection and Quarantine (2008), the nominal vertical uncertainties of the topographic maps are controlled within 10-16 m over mountain regions (with slopes of $6^{\circ}-25^{\circ}$ ) and $16-28 \mathrm{~m}$ over steep mountains (with slopes of $>25^{\circ}$ ). The average slope of WKM glaciers is $11.2^{\circ}$ (calculated based on Shuttle Radar Topography Mission (SRTM) DEM) and hence we consider the averaged vertical accuracy of these topographic maps may be better than $16 \mathrm{~m}$ on the glacierized terrain. It is noted that topographic data are derived from stereo photogrammetry, which often suffers from errors and gaps over the snow accumulation zones because of low radiometric contrast, leading to the larger uncertainty $(>16 \mathrm{~m})$ in these regions.

\subsubsection{SRTM DEM}

The SRTM DEMs are constructed by means of C-band and Xband Spaceborne Imaging Radar operating in interferometric mode aboard the space shuttle Endeavour from 11 to 22 February 2000, and has been widely applied for glacier investigations (e.g. Kääb and others, 2008; Gardelle and others, 2013; Bao and others, 2015). SRTM C-band DEM is available over the entire globe between $60^{\circ} \mathrm{N}$ and $57^{\circ} \mathrm{S}$. However, the X-band DEM's coverage is not continuous and fails to cover our whole study region because of its narrow swath widths. Therefore, we use C-band DEM for the estimate of glacier changes. Assuming the radar beam 
fully penetrating into snow (Paul and Haeberli, 2008), the resulting DEM is considered to be representative of the glacier surface at the end of the 1999 ablation period (Gardelle and others, 2013). The geodetic reference for SRTM C-band DEM is the World Geodetic System 1984 (WGS84), defined as the 1996 Earth Gravitational Model (EGM96) geoid. The horizontal and vertical datum of $\mathrm{X}$ band SRTM DEM is WGS84 ellipsoid. The original SRTM data contain data gaps, especially at high and steep regions because of heavy shadows and layover effects. The voids on the glacierized surface of WKM account for $0.52 \%$ of glacier total areas for the 1970s, and Figure S1 presents their spatial distribution. To render the data more useful, the voids in C-band DEM have been filled by the Consortium for Spatial Information of the Consultative Group for International Agricultural Research (CGIAR-CSI) (Jarvis and others, 2008). The C-band DEM data for regions outside the USA has a spatial resolution of 3 arc-seconds ( 90 m) (SRTM3).

\subsubsection{ICESat elevation}

The Geoscience Laser Altimeter System (GLAS) onboard ICESat provides surface elevation data in several campaigns, with horizontal and vertical accuracies of $10.6 \pm 4.5$ and $0.34 \mathrm{~m}$, respectively (Magruder and others, 2007; available online at http://www.nsidc.org). The laser footprints have $172 \mathrm{~m}$ spacing along-track, and $\sim 42 \mathrm{~km}$ cross-track spacing between 91 day repeat. Because of the reliability of vertical reference of GLAS elevations for stable ground control points (Kääb, 2008; Nuth and Kääb, 2011), the GLAS14 product is used to evaluate the quality of DEM70 and SRTM DEM. ICESat/GLAS elevations are referenced to the TOPEX/Poseidon ellipsoid.

\subsubsection{Landsat images}

Table 1 summarizes all the cloud-free Landsat MSS, TM/ ETM+ and 8 Operational Land Imager (OLI) images used in this study. Landsat MSS images have $57 \mathrm{~m}$ horizontal resolution and have one thermal, two near-infrared and two visible bands. The spatial resolution of TM images is $30 \mathrm{~m}$, including one near infrared band two short-infrared bands, one thermal band and three visible bands (i.e. blue, green and red). Different from TM images, the ETM+ images have a $15 \mathrm{~m}$ resolution panchromatic band, which is often used to merge with other TM bands to improve the resolution of images. The Landsat 8 satellite launched 11 February 2013 and has two push-broom instruments, i.e. the OLI sensor and the Thermal Infrared Sensor (TIRS), which can be used to enhance the radiometric signal-to-noise and to improve characterization of land cover state and condition. New deep blue visible and shortwave infrared bands are included in the OLI sensor to improve the prior Landsat instruments.

\subsection{Methods}

\subsubsection{Datum transformation}

To make the DEM70 and C-band SRTM-DEM (topographical maps and Landsat images) under the same horizontal coordinate system, a seven parameter transformation is used to transform the Xian 80 data into the WGS84 data:

$$
\left[\begin{array}{l}
X_{84} \\
Y_{84} \\
Z_{84}
\end{array}\right]=M \times\left[\begin{array}{l}
1-w_{Z}+w_{Y} \\
w_{Z}+1-w_{X} \\
-w_{Y}+w_{X}+1
\end{array}\right] \times\left[\begin{array}{l}
X_{80} \\
Y_{80} \\
Z_{80}
\end{array}\right]+\left[\begin{array}{l}
X_{0} \\
Y_{0} \\
Z_{0}
\end{array}\right]
$$

where $X_{84}, Y_{84}$ and $Z_{84}$ are the WGS84 datum coordinates, $X_{80}, Y_{80}$ and $Z_{80}$ are the Xian 80 datum coordinates, $X_{0}, Y_{0}$ and $Z_{0}$ are the translation parameters, $w_{X}, w_{Y}$ and $w_{Z}$ are the rotation parameters, and $M$ is the scale factor. Three known national trigonometric points are used to evaluate these parameters for each map. The uncertainty of this seven-parameter transformation is estimated to be $<0.5 \mathrm{~m}$ (Gao and others, 2009).

An IDL program acquired from NSIDC (https://nsidc.org/ data/icesat/geoid.html) is used to convert the TOPEX/ Poseidon ellipsoid of GLA14 data to the WGS 84 ellipsoid, and further to EGM96 geoid based on the model from the National Geospatial-Intelligence Agency (NGA)/NASA (http://earth-info.nga.mil/GandG/wgs84/gravitymod/egm96/ egm96.html). We also use this NGA/NASA model to transform the vertical reference datum of SRTM X-band DEM to the EGM96 geoid.

\subsubsection{DEM co-registration}

Subtracting the DEM70 from the SRTM-DEM, difference maps are constructed to compare elevation deviations on a cell-by-cell basis. We first calculate the difference of DEM70 relative to SRTM-DEM by excluding nonstable terrain such as glaciers, lakes and ice-cored moraines. The elevation difference is strongly affected by topographical slope and aspect (Fig. 2; Nuth and Kääb, 2011). To minimize the horizontal displacements on stable terrain, DEM70 is Coregistered to SRTM-DEM using the following equation

Table 1. List of data for the WKM glacier change assessment

\begin{tabular}{|c|c|c|c|c|c|c|}
\hline Data & Date & Pixel size/Scale & Path/Row & Cloud coverage $(\%)$ & Purpose & Resource \\
\hline SRTM & February 2000 & $90 \mathrm{~m}$ & - & & DEM & CGIAR-CSI \\
\hline Topographical maps & September-October 1968-71 & 1: 100000 & - & & DEM/base image & CMGS \\
\hline Landsat MSS & February 1977 & $57 \mathrm{~m}$ & $156 / 35$ & 0 & Reference image & GLCF \\
\hline Landsat TM & November 1990 & $30 \mathrm{~m}$ & $145 / 35$ & $<1$ & Reference image & GLCF \\
\hline Landsat TM & November 1990 & $30 \mathrm{~m}$ & $145 / 36$ & $<1$ & Reference image & GLCF \\
\hline Landsat ETM+ & October 1999 & $30 \mathrm{~m}$ & $145 / 35$ & 2 & Base image & GLCF \\
\hline Landsat 8/OLI & October 2016 & $15 \mathrm{~m}$ & $145 / 35$ & 4.56 & Base image & USGS \\
\hline Landsat 8/OLI & October 2016 & $15 \mathrm{~m}$ & $145 / 36$ & 2.84 & Base image & USGS \\
\hline Landsat 8/OLI & September 2016 & $15 \mathrm{~m}$ & $145 / 35$ & 4.05 & Reference image & USGS \\
\hline Landsat 8/OLI & September 2016 & $15 \mathrm{~m}$ & $145 / 36$ & 15.72 & Reference image & USGS \\
\hline
\end{tabular}



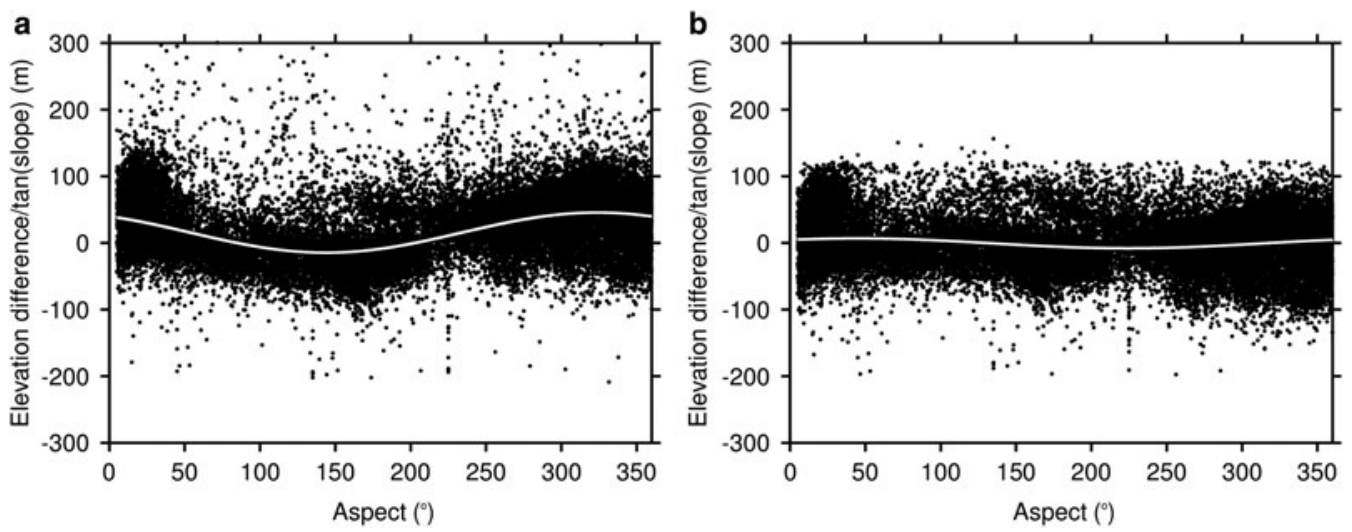

Fig. 2. Scatter plot of slope standardized elevation differences between DEM70 and SRTM DEM vs. aspect (a) before co-registration and (b) after co-registration.

described by Nuth and Kääb (2011).

$$
\frac{d h}{\tan \alpha}=a \cos (b-\varphi)+c
$$

where $\alpha$ and $\varphi$ denote the topographic slope and aspect, respectively, and $a, b$ and $c$ represent the shift vector magnitude and direction and the averaged difference of the two DEMs. Before co-registration, the pixels with a slope angle of $<5^{\circ}$ are discarded. A least-squares optimization is used to calculate the parameters $a, b$ and $c$. This process is iterated to reach an ultimate solution when the length of the solved shift vector is $<1 \mathrm{~m}$. The resulting horizontal shifts are $19.3 \mathrm{~m}$ in $X$-direction and $-23.0 \mathrm{~m}$ in $Y$-direction (Table 2). The vertical bias (Z-offset) is $6.9 \mathrm{~m}$. The vertical RMSE of elevation difference for off-glacier terrain after the correction decreases $\sim 20 \%$ compared with that before the correction. Based on this co-registration method, we also co-register DEM70 and SRTM DEM to ICESat data to estimate their vertical accuracy.

\subsubsection{DEMs accuracy}

We use ICESat data to assess DEM70 and SRTM elevation data prior to the quantification of glacier elevation changes. The surface elevation accuracy of DEM70 is tested by a comparison with the GLA14 over ice-free stable areas. In total 2301 GLAS footprints during 2003-09 are available over the barren areas of the WKM. ICESat elevation differences $>100 \mathrm{~m}$ relative to DEM70 and SRTM DEMs are regarded as outliers resulting from the cloud reflections, saturated waveforms, or inaccurate regions of the DEM70 or SRTM data and thus are excluded from the evaluation. ICESat footprints with a slope angle of $>15^{\circ}$ are also omitted to ensure that the vertical uncertainty of GLA14 data are $<1 \mathrm{~m}$ (Beaulieu and Clavet, 2009; Pieczonka and others, 2013). After the outlier exclusion, 1810 ICESat data are left for the assessment of DEM70 and SRTM DEM accuracy. The resulting surface elevation difference between DEM70 and GLAS ICESat data has the averaged value and RMSE of 0.3 and $10.9 \mathrm{~m}$. The averaged value and RMSE of the difference between available GLAS data and SRTM in the WKM are -0.1 and $9.8 \mathrm{~m}$, respectively. Due to the limited available number of ICESat GLAS data, further corrections are performed using the difference between SRTM DEM and DEM70 rather than individual DEM adjustment based on ICESat data.

\subsubsection{Correction of terrain curvature and SRTM radar penetration}

As pointed out by previous studies (Berthier and others, 2006; Paul, 2008; Gardelle and others, 2012b), elevationdependent vertical bias in mountainous regions is attributable to differences in the original spatial resolution of the two DEMs. The coarse DEM is prone to underestimate the heights of the sharp peaks or ridges with high terrain curvature due to its limited capacity of the representation of high-frequent changes in slopes. This bias can be corrected by the relationship between elevation difference and maximum curvature over the stable terrain off glaciers (Gardelle and others, 2012b, 2013). A clear polynomial relationship is found between the two variables and thus in this study, a cubic-polynomial fitting is utilized to make the correction (Fig. 3a).

For glacier covered by snow and firn, SRTM data map a surface which is below the real glacier surface because of penetration of the C-band radar signal. This penetration depth varies from 0 to $10 \mathrm{~m}$ (e.g. Barundun and others, 2015; Fischer and others, 2015; Kääb and others, 2015). A geodetic mass balance without any correction for this penetration will likely be severely biased in the dry cold climate of

Table 2. Shift vectors in $X, Y$ and $Z$ directions and the uncertainty in DEM before and after co-registration

\begin{tabular}{|c|c|c|c|c|c|c|c|c|}
\hline \multicolumn{3}{|c|}{$\begin{array}{l}\text { Shift vectors in } X, Y \text { and } Z \\
\text { directions }\end{array}$} & \multicolumn{3}{|c|}{ Before co-registration } & \multicolumn{3}{|c|}{ After co-registration } \\
\hline$X(\mathrm{~m})$ & $Y(\mathrm{~m})$ & $Z(\mathrm{~m})$ & Mean bias (m) & $\mathrm{SD}(\mathrm{m})$ & RMSE (m) & Mean bias (m) & $\mathrm{SD}(\mathrm{m})$ & RMSE (m) \\
\hline 19.3 & -23 & 6.9 & 6.8 & 17.3 & 18.6 & -0.1 & 14.8 & 14.9 \\
\hline
\end{tabular}

SD, standard deviation; RMSE, root mean square error. 

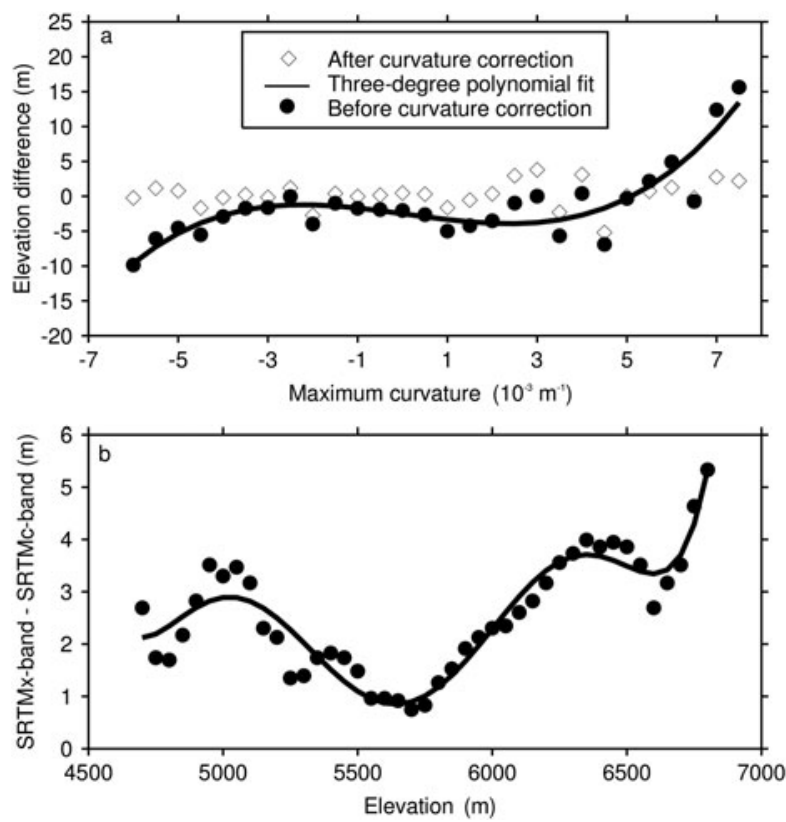

Fig. 3. (a) Relationship between elevation difference and maximum curvature; (b) Relationship between SRTM C band snow penetration depth and elevation.

the WKM. Here, we estimate this penetration by differencing the SRTM C-band $(5.7 \mathrm{GHz})$ and X-band $(9.7 \mathrm{GHz})$ DEMs, as done by Gardelle and others (2012b, 2013), due to the lower penetration of the X-band than C-band. Based on this method, the SRTM C-band DEM elevations are compared with the simultaneously acquired X-band SRTM DEM covering $\sim 70 \%$ of the icefield. The resulting averaged SRTM $M_{C-\text { band }}$ penetration over WKM glaciers is estimated to be $\sim 2.8 \mathrm{~m}$. We determine the relationship between the penetration depth in each $50 \mathrm{~m}$ elevation bin and the corresponding glacier altitude (Fig. 3b). Following Gardelle and others (2013), the correction is performed using the elevation difference (SRTM $\mathrm{X}_{\mathrm{X} \text {-band }}-\mathrm{SRTM}_{\mathrm{C}-\text { band }}$ ) as a function of altitude (a six-order polynomial fitting, Fig. 3b) at each glacierized pixel.

\subsubsection{Glacier extent delineation and geodetic mean elevation change calculation}

Before glacier outline delineation, all Landsat images are coregistered to the topographical maps using 30-45 easily identified ground control points (GCPs) and the accuracy of coregistration is $\sim 20 \mathrm{~m}$ (slightly more than half of one pixel of Landsat images). Glacier outlines from the topographical maps are manually digitized and then corrected by Landsat MSS images taken in 1977. The resulting glacier boundaries are then manually adjusted to reflect the glacier outlines in 1999 and 2016 by means of the visual interpretation of coregistered Landsat TM/ETM+ and 8 OLI images.

Prior to elevation change calculations, we exclude data that meet the following conditions:

- Void-filled regions of the SRTM DEM

- Slopes $>30^{\circ}$ (Pieczonka and others, 2011)

- Absolute elevation changes $>100 \mathrm{~m}$

- For nonsurging glaciers, we exclude (1) elevation changes $>$ or $<3$ standard deviations of the mean in each $100 \mathrm{~m}$ elevation band and (2) elevation changes that are $>68.3$ and $<31.7$ quantiles of elevation change in the accumulation area (Holzer and others, 2015)

- For surging glaciers, we use the filtering method of Pieczonka and Bolch (2015) which applies a sigmoid function that allows for a larger range of elevation change in ablation areas and a narrower range at the glacier head.

Missing data below the ELA are replaced by kriging and data gaps in the accumulation area are filled using the average elevation change of the appropriate $100 \mathrm{~m}$ elevation band.

Fluctuations in glacier length and elevation changes in surge-type glaciers are controlled by internal instabilities and are typically independent of climate change, whereas for nonsurge-type glaciers these are more closely related to climate changes. To better examine the cause of WKM glacier changes, we calculate area changes and geodetic mass balances separately for surge-type glaciers, nonsurgetype glaciers and all glaciers (cf. Citterio and others, 2009). The averaged elevation change for the WKM glaciers is assessed as an area-weighted averaged elevation difference per $100 \mathrm{~m}$ altitude bin. We transform elevation change to mass balance by using a constant density of $850 \pm 60 \mathrm{~kg}$ $\mathrm{m}^{-3}$ (Huss, 2013).

\subsubsection{Uncertainty assessment}

The uncertainties of the glacier areas and area changes are estimated using a buffering method as described by Minora and others (2016). This method considers both the uncertainty from the data sources (satellite images, topographic maps and aerial photos) and the clarity of glacier limits (Vögtle and Schilling, 1999; Citterio and others, 2007). The error for the whole glacier coverage is computed by taking the root of the squared sum of the buffer perimeter of each glacier. Additionally, we take into account the error of coregistration from the different images. The final estimate formula is:

$$
E_{\text {area }}=\sqrt{\sum_{i=1}^{n}\left(p_{i} \cdot \sqrt{L R E_{\mathrm{yr}}^{2}+E_{\mathrm{co}}^{2}}\right)}
$$

where $E_{\text {area }}$ is the areal error, and $p_{i}$ and $n$ are the $i^{\text {th }}$ glacier perimeter and the number of glaciers, respectively. $L R E_{y \mathrm{r}}$ is the Linear Resolution Error affecting topographical map and Landsat images from the different years. $E_{\mathrm{co}}$ represents the error of co-registration (20 m). Following O'Gorman (1996), $L R E_{\mathrm{yr}}$ is half a pixel for the outline delineation and thus in this study, it is $15 \mathrm{~m}$ for the Landsat TM images, $7.5 \mathrm{~m}$ for Landsat 8/OLI images and $25 \mathrm{~m}$ for the 1: 100000 topographical maps. It is noted that this error may be too low for debris-covered pixels because glacier extents are more difficult to distinguish when ice is covered by debris (Paul and others, 2009). Therefore, errors on the debris pixels are regarded as three times those of clean ice. Finally, the total error in area change is calculated as the following format.

$$
\Delta E_{\text {area }}=\sqrt{E_{\mathrm{A} 1}^{2}+E_{\mathrm{A} 2}^{2}}
$$

where $\Delta E_{\text {area }}$ represents an error in changes in glacier area, and $E_{\mathrm{A} 1}$ and $E_{\mathrm{A} 2}$ are the uncertainties of the outlines of glaciers at different periods. 
Table 3. Area changes for glaciers in the WKM

\begin{tabular}{|c|c|c|}
\hline WKM glaciers & $\Delta$ area $_{1970 \mathrm{~s}-2016}\left(\mathrm{~km}^{2}\right)$ & $\Delta$ area $_{1970 \mathrm{~s}-2016}\left(\% \mathrm{a}^{-1}\right)$ \\
\hline Surging glaciers & 11 & $-0.02 \pm 0.09$ \\
\hline Non-surging glaciers & 100 & $-0.14 \pm 0.11$ \\
\hline All glaciers & 111 & $-0.07 \pm 0.10$ \\
\hline
\end{tabular}

Following Gardelle and others (2013), the uncertainty of the glacier elevation change is calculated after the exclusion of nonstable terrain using the two DEMs.

$$
U_{\Delta \mathrm{h}}=\frac{U_{\Delta \mathrm{hi}}}{N_{\mathrm{eff}}}
$$

where $U_{\Delta h i}$ represents the Std dev. of the averaged elevation change in each altitude band for off-glacier terrain and $N_{\text {eff }}$ is the effective number of measurements:

$$
N_{\text {eff }}=\frac{P \times N_{\text {tot }}}{2 d}
$$
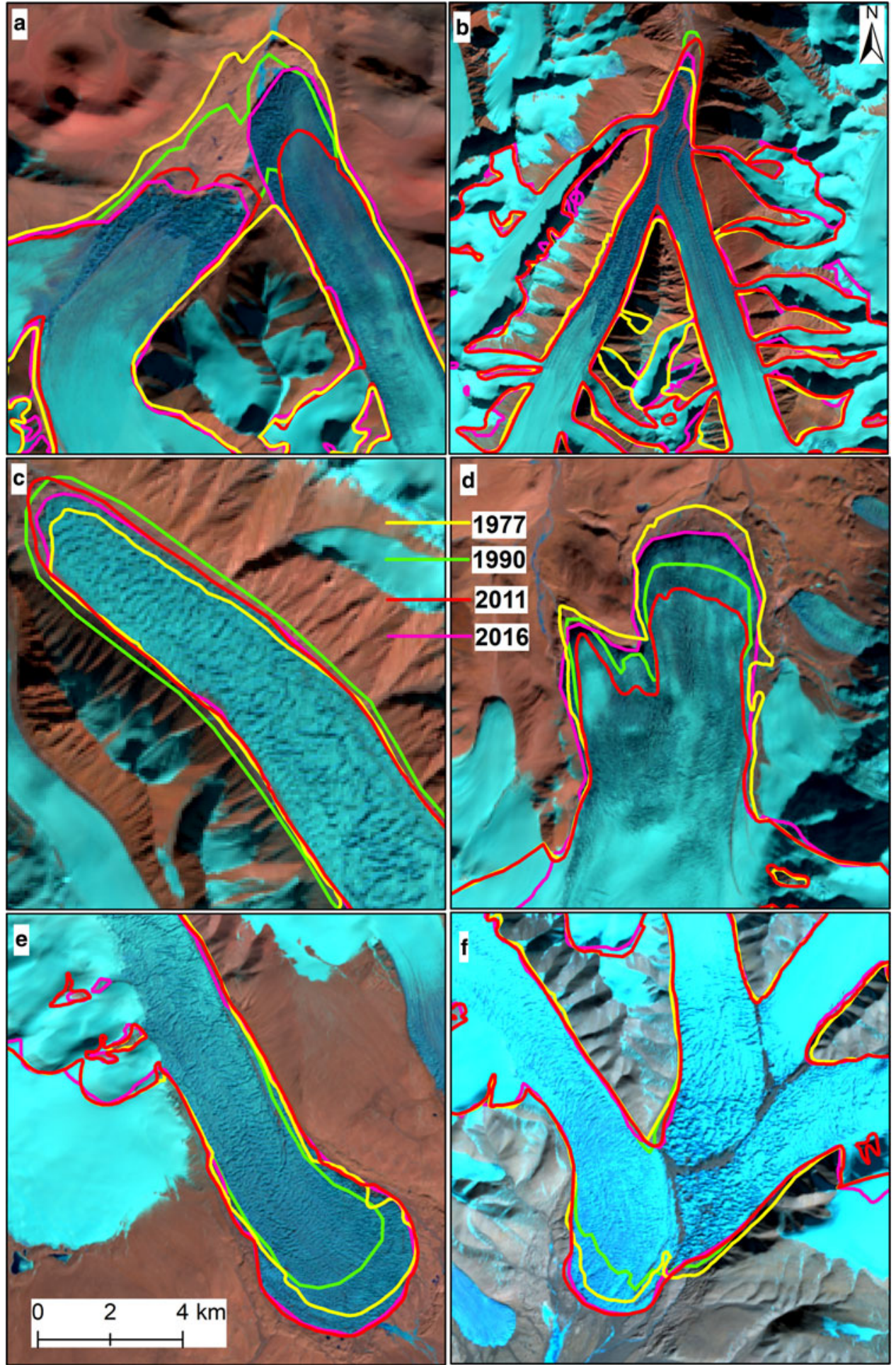

Fig. 4. Terminus positions at different time spans for (a) West Kunlun Glacier, (b) Kunlun Glacier, (c) Yulong Glacier, (d) Alakeasyi Glacier, (e) Chongce Glacier and (f) Zhongfeng Glacier. 
where $N_{\text {tot }}$ is the total number of measurements, $P$ is the pixel size $(30 \mathrm{~m})$ and $d$ is the distance of spatial autocorrelation $(810 \mathrm{~m})$, which is calculated by Moran's I autocorrelation index.

Furthermore, the uncertainties in the penetration correction, ice density and mapped glacier extents are also considered. Penetration correction error $\left(U_{\mathrm{p}}\right)$ is assumed to be \pm 1 $\mathrm{m}$, which is the maximum difference of two penetration estimate methods from Gardelle and others (2013) and Kääb and others (2015), respectively. Following Huss (2013), glacier ice density uncertainty $\left(U_{\mathrm{d}}\right)$ is $\pm 60 \mathrm{~kg} \mathrm{~m}^{-3}$, i.e. $\pm 7 \%$ of the elevation change. The uncertainty of the glacier area $\left(U_{\mathrm{a}}\right)$ is $<4 \%$, based on the area error estimate method as describe above, and thus $4 \%$ is applied for the elevation change error calculation. The final uncertainty $(U)$ is calculated based on the sum of these individual uncertainties:

$$
U=\sqrt{U_{\Delta \mathrm{h}}^{2}+U_{\mathrm{a}}^{2}+U_{\mathrm{p}}^{2}+U_{\mathrm{d}}^{2}}
$$

\section{RESULTS}

\subsection{Area change}

There are 389 glaciers with elevation change calculation in the WKM region, covering an area of $3079 \pm 105 \mathrm{~km}^{2}$ in $1968-71$. These glaciers have shrunk to $2968 \pm 103 \mathrm{~km}^{2}$ in 2016. Hence, the glacier area shrinkage rate is $3.6 \pm 4.8 \%$ or $0.07 \pm 0.1 \% \mathrm{a}^{-1}$ (Table 3), which is not significant. Area changes over the past 40 years are characterized by spatial and temporal heterogeneity. As shown in Figure 4, Xikunlun Glacier experiences terminus retreat for the 1977-90 and 1990-2011 periods, and advance during 2011-16, while Chongce Glacier retreats between 1977 and 1990 and advances from 1990 to 2011, then remains stable until 2016. Overall, some glacier tongues advance, while most are stable or retreating from 1968-71 to 2016. Non-surging glaciers exhibit low or insignificant area changes, with a mean area loss of $100 \mathrm{~km}^{2}(-0.14 \pm 0.12 \%$ $\mathrm{a}^{-1}$ ) between 1968-71 and 2016. In comparison, surge- type glaciers show a mean area loss of $11 \mathrm{~km}^{2}(-0.02 \pm$ $0.09 \% \mathrm{a}^{-1}$ ) over the same period.

\subsection{Mass change}

Between 1968-71 and 1999, we observe a heterogeneous pattern of surface elevation changes in the WKM. We thus divide the WKM into western, central and eastern parts (Fig. 5), and calculate mass changes (Fig. 5) and altitudinal distribution of thickness changes (Fig. 6) of nonsurging and surging glaciers separately for each region. A mass gain $\left(0.13 \pm 0.15 \mathrm{~m}\right.$ w.e. $\left.\mathrm{a}^{-1}\right)$ is observed in the western WKM nonsurging glaciers, whereas central WKM nonsurging glaciers experience a mass loss of $-0.08 \pm 0.15 \mathrm{~m}$ w.e. $\mathrm{a}^{-1}$. Non-surging glacier mass loss over the eastern WKM is greatest $\left(-0.16 \pm 0.15 \mathrm{~m}\right.$ w.e. $\left.\mathrm{a}^{-1}\right)$. In contrast to mass gain of nonsurging glaciers over the western WKM, surging glaciers exhibit an insignificant mass loss. Over the central and eastern WKM, there is no distinct difference of mass change between surging and nonsurging glaciers.

In the elevation bins above $5600 \mathrm{~m}$, nonsurging glaciers over the western WKM show rather constant thickening rates (Fig. 6a), whereas small thinning rates are observed for nonsurging glaciers over the central and eastern WKM (Figs. 6c, e). Although the surging glaciers over the western and eastern WKM exhibit significant thickening rates in each elevation bin below 5600 m (Figs 6b, f), several thinning rates are found in the surging glaciers in the central WKM at elevation bins below $5300 \mathrm{~m}$ (Fig. 6d)

Surface elevation changes vary significantly both within and between glaciers. The western branch of Kunlun Glacier, for example, has high thinning rates at middle elevations and elevation increases larger than $40 \mathrm{~m}$ at its terminus (Fig. 7a). More typical patterns of thinning at the terminus and slight elevation gains in the accumulation area are observed over Gongxing and West Kunlun Glaciers (Fig. 7b). A switch between quiescent and surging phases of the Zhongfeng Glacier is demonstrated by thinning at the terminus and thickening in its middle elevations in 1980-99 (Fig. 7d),

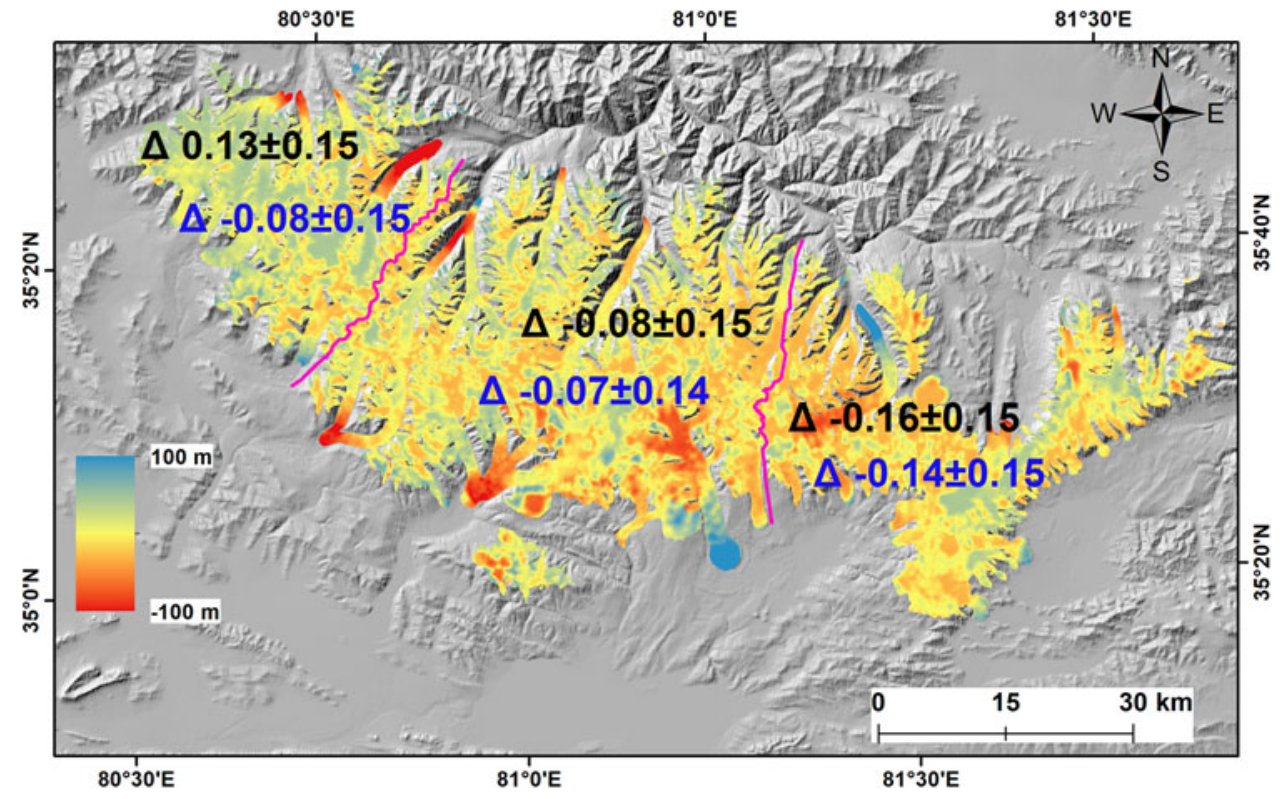

Fig. 5. Surface elevation changes of WKM glaciers between the 1970s and 1999. Glaciers are divided into western, central and eastern parts by purple lines. Their annual mean mass balances are indicated in units of $\mathrm{m}$ w.e. $\mathrm{a}^{-1}$ (blue: surging glaciers, and black: nonsurging glaciers). 

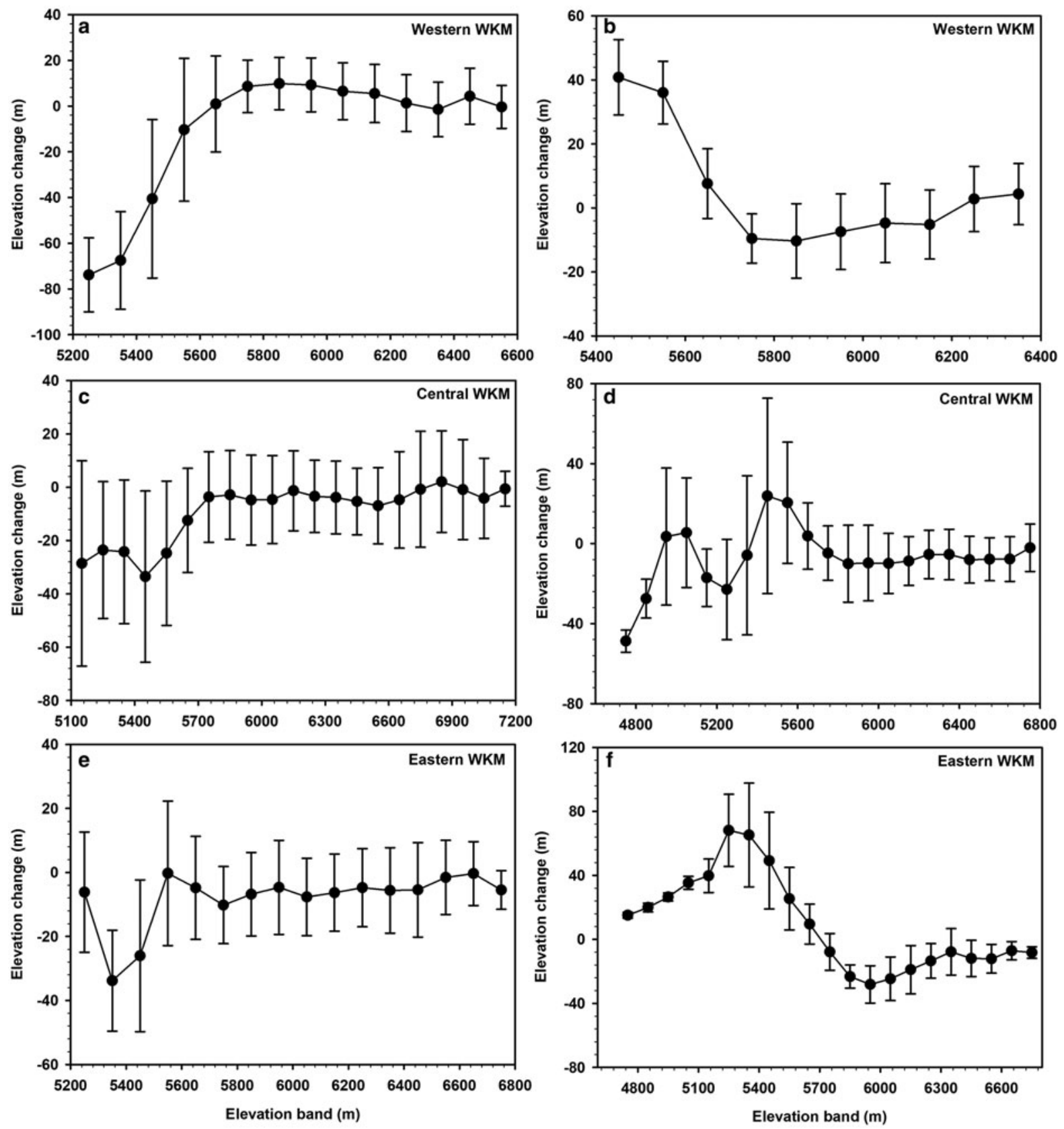

Fig. 6. Altitudinal distribution of thickness changes of nonsurging ( $a, c$ and $e$ ) and surging $(b, d$ and $f$ ) glaciers over the western, central and eastern WKM. Error bars present Std dev. of glacier height changes in each elevation bin.

followed by thinning in the middle elevations and bulging at the glacier terminus after 2003 (Yasuda and Furuya, 2013; Ke and others, 2015).

Strong thickening in the downstream part and significant thinning over the upstream part are observed on a few glaciers, for example Bulakebashi Glacier (Fig. 6c), Yulong Glacier (Fig. 6c), Chongce Glacier, Kunlun Glacier and N6 Glacier, which are characteristic of surging glaciers.

\section{DISCUSSION}

\subsection{Glacier area and surface elevation change}

Glacier outlines of the CGI from GLIMS, which are published in 2002 and are based on topographical maps obtained from aerial photographs from the 1950s to the 1980s (Shi and others, 2010), have potential application for the investigation of glacier changes. However, the quality of the CGI is reported to be poor based on comparison with Landsat 8 OLI images over WKM (Ke and others, 2015). Therefore, we do not use the inventory data, but manually digitize the boundaries of glaciers on the topographical maps. Because of the possible uncertainty in the boundaries of glaciers presented on the topographic maps (Bolch and others, 2010), we further correct the outlines based on Landsat MSS images. Combined with Landsat 8 OLI images in 2016, the determined area change reduction of both surging and nonsurging glaciers is $-3.6 \pm 4.8 \%\left(-0.07 \pm 0.1 \% \mathrm{a}^{-1}\right)$ in the last 40 years, which is comparatively small and within the calculation uncertainty. The slight area reduction rate agrees well with the previously published results from $\mathrm{Ji}$ and others (2013), Wei and others (2014) and Bao and others (2015). However, our calculated shrinkage rate $\left(-0.07 \pm 0.1 \% \mathrm{a}^{-1}\right)$ is higher than the area decrease rate $\left(\sim-0.02 \% \mathrm{a}^{-1}\right)$ from 

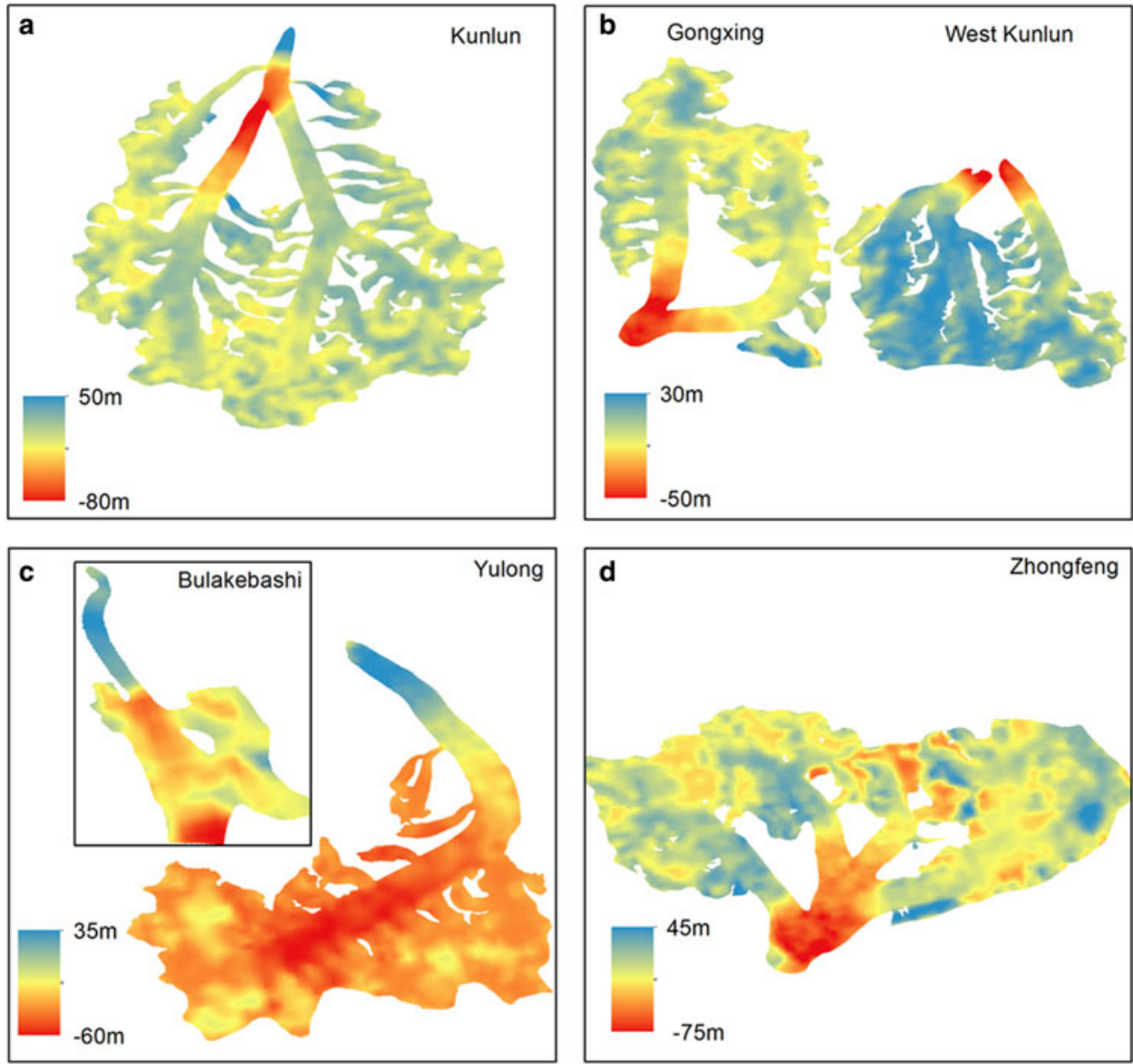

Fig. 7. Surface elevation changes for (a) Kunlun Glacier, (b) Gongxing Glacier and West Kunlun Glacier, (c) Yulong Glacier and Bulakebashi Glacier, and (d) Zhongfeng Glacier.

1970 to 2000 determined by Shangguan and others (2007). The different glacier area shrinkage rate may result from the different investigation period, the uncertainty in glacier extent from the Chinese topographic maps (Bolch and Schneider 2010) and the difficulty in the glacier interpretation based on the coarser resolution Landsat imagery. Furthermore, a detailed assessment of glacier extent uncertainty is absent in Shangguan and others (2007). Compared with multi-decadal glacier shrinkage rates of -0.57 to $-0.40 \% \mathrm{a}^{-1}$ found for High Mountain Asia (Cogley, 2016), the WKM glacier area shrinkage rate is an order of magnitude lower (Table 3).
In recent decades, WKM glacier mass-balance evaluations have been performed based on the available gravimetric (GRACE) and ICESat observations (Bao and others, 2015; Gardner and others, 2013; Kääb and others, 2015; Ke and others, 2015). Gardner and others (2013) have found an average thickening of $0.17 \pm 0.15 \mathrm{~m} \mathrm{a}^{-1}$ from 2003 to 2009 by analyzing ICESat footprints and GRACE observations for WKM. Slightly lower rate of increase in surface elevation $\left(0.05 \pm 0.07 \mathrm{~m} \mathrm{a}^{-1}\right)$ has been estimated by Kääb and others (2015) using ICESat measurements in relation to SRTMDEM. Ke and others (2015) and Bao and others (2015) also used ICESat laser altimetry to determine the WKM glacier
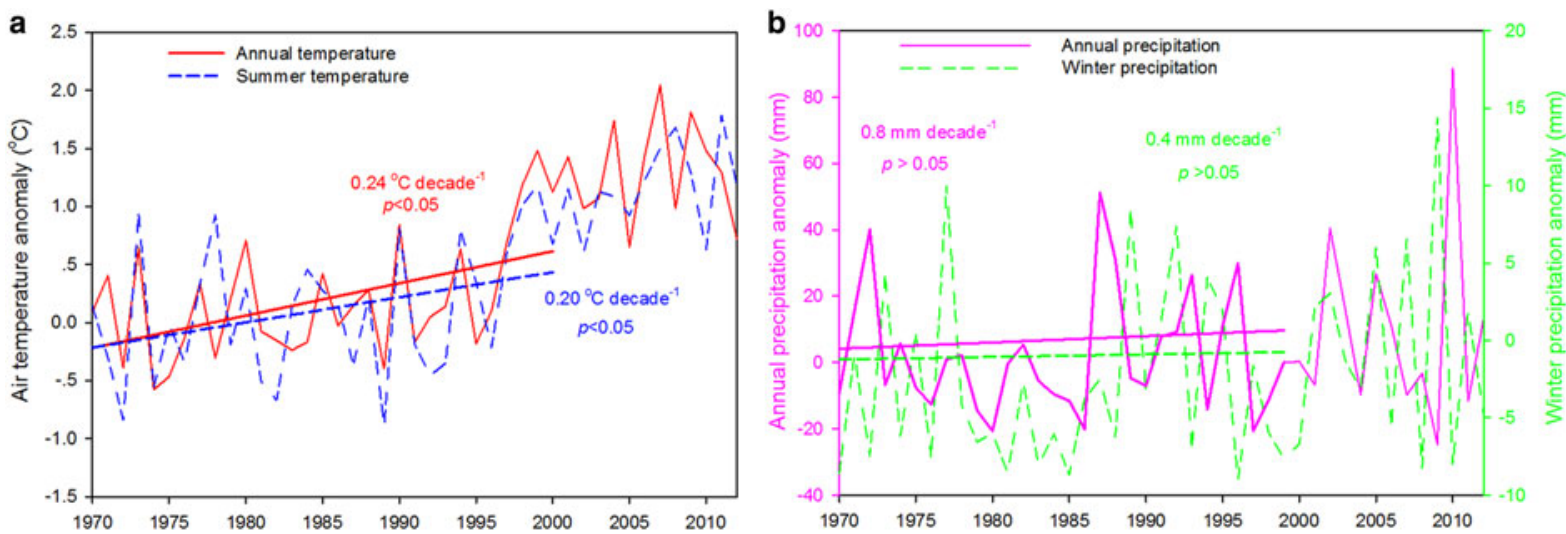

Fig. 8. Temporal variations of (a) averaged annual and summer (June, July, August and September) air temperature and (b) annual and winter (November, December, January and February) precipitation of the five meteorological stations nearest to the WKM from 1970 to 2012. 

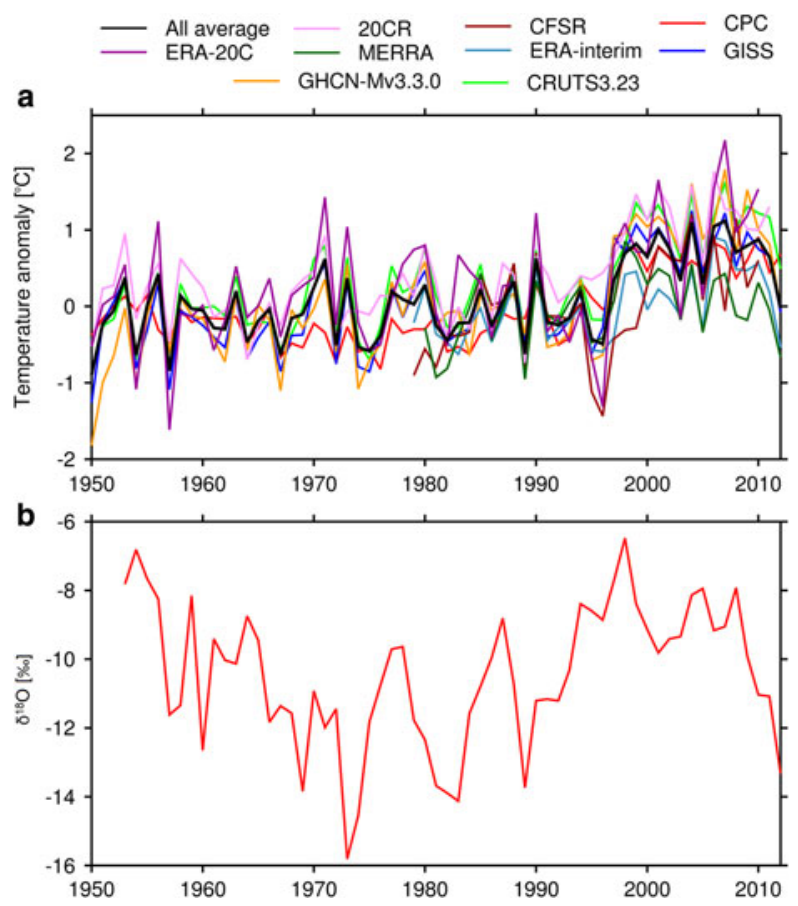

Fig. 9. Time series of air temperature from nine reanalyses for the northwestern Tibetan Plateau $\left(33-39^{\circ} \mathrm{N}, 71-82^{\circ} \mathrm{E}\right)$ including ERAInterim, MERRA, CFSR, GISS, 20CR, ERA-20C, CRU, GHCN-M and $\mathrm{CPC}(\mathrm{a})$, and $\delta^{18} \mathrm{O}$ records from Chongce ice core from An and others (2016).

elevation change between 2003 and 2008, and the determined elevation increase rate is $>0.20 \mathrm{~m} \mathrm{a}^{-1}$. The relatively high thickening rate probably results from their uncorrected SRTM C band penetration. Based on the difference of DEM70 relative to SRTM-DEM, averaged elevation change is $-0.06 \pm 0.19 \mathrm{~m}$ w.e. $\mathrm{a}^{-1}$ for the glaciers on the WKM region from 1970s to 1999. In addition, Lin and others (2017) reported a mass gain of $0.128 \pm 0.055 \mathrm{~m}$ w.e. $\mathrm{a}^{-1}$ for WKM glaciers from 2000 to 2014, based on the difference between SRTM DEM and TerraSAR-X DEM. Therefore, WKM glacier mass is probably balanced or changing only slightly since the 1970s. At Muztagh Ata and Kongur Tagh (eastern Pamir), geodetic measurements show glacier masses are balanced or nearly balanced since the 1970s (Holzer and others, 2015; Zhang and others, 2016). At Hunza catchment of Karakoram, the averaged glacier mass budgets are slightly but insignificantly negative between 1973 and 1999 and positive after 1999 (Bolch and others, 2017). These results show that the Pamir-Karakoram-WKM anomaly may be at least put back to the 1970s and are consistent with recent publications (Forsythe and others, 2017; Zhou and others, 2018).

\subsection{Glacier surging}

The spatial pattern of elevation changes reveals that surgetype glaciers are widely distributed in the WKM. They can be easily identified by the marked thinning over the accumulation area and thickening on the ablation area. It is clearly seen that surge events have happened over Chongce Glacier, Yulong Glacier, N6 Glacier, Kunlun Glacier and Bulakebashi Glacier from the 1970s to 1999. This agrees with velocity, terminus position and morphology changes determined from SAR images during 1972-2014 (Yasuda and Furuya, 2015). In addition, N4 Glacier, N5 Glacier and the eastern branches of Duofeng Glacier and Duota Glacier present surge-type elevation change character. They are regarded by Yasuda and Furuya (2015) as possible surge-type glaciers because no active surge was observed. The similar mass changes of surge-type and nonsurge-type glaciers suggest that the glacier internal instabilities seem not to have a significant impact on the glacier mass balance over WKM. Similar mass budgets for surging and nonsurging glaciers have been also reported in the Pamirs and Karakoram (Gardelle and others, 2013).

\subsection{Climate consideration}

Glacier changes are related to a larger-scale meteorological or climatic feature. Here, we collect the monthly air temperature and precipitation observations from five meteorological stations (Pishan, Hetain, Yutain, Minfeng and Shiquanhe, Fig. 1 and Table S1) near to the WKM glaciers. The data are derived from the National Meteorological Information Center, China Meteorological Administration. Based on the averaged records from the five meteorological stations, it is found that from 1970 to 1999, annual and summer mean air temperature shows the significant upward trends of $0.24 \pm 0.10^{\circ} \mathrm{C}$ decade $^{-1} \quad(p<0.01)$ and $0.20 \pm 0.12{ }^{\circ} \mathrm{C}$ decade $^{-1}(p<0.01)$, respectively. However, the upward trends are not significant for the 2000-12 period (Fig. 8a). In October 2012, three ice cores with the length of 133.83 $\mathrm{m}, 135.81 \mathrm{~m}$ and $58.82 \mathrm{~m}$ were recovered from Chongce ice cap $\left(35^{\circ} 14^{\prime} \mathrm{N}, 81^{\circ} 07^{\prime} \mathrm{E}, 6010 \mathrm{~m}\right.$ a.s.I., see Fig. 1) (An and others, 2016). Stable oxygen isotope ratios are positively correlated with annual mean air temperature recorded at Shiquanhe and the ice core temperature trend calculated between 1970 and $1999\left(0.74 \pm 0.12{ }^{\circ} \mathrm{C}\right.$ decade $\left.^{-1}\right)$ is greater than that observed from station data. In consideration of the scarceness of the meteorological stations around WKM glaciers, the nine high-resolution reanalyses (Table S2) for this region $\left(33-39^{\circ} \mathrm{N}, 71-82^{\circ} \mathrm{E}\right)$ are compared with the available observations to further determine the air temperature variability. The results also show that significant warming occurs between 1970 and 1999, but variability in the air temperature is not significant since 2000 (Fig. 9). Meteorological station measurements reveal an insignificant increase in the annual and winter (November-April) precipitation for the 1970-99 and 2000-12 time spans (Fig. 8b). Based on the gridded precipitation fields from Global Precipitation Climatology Project (GPCP) Combined Precipitation Data Set, WKM and surrounding $\left(33-39^{\circ} \mathrm{N}\right.$, $\left.71-82^{\circ} \mathrm{E}\right)$ experience a significantly increasing annual precipitation trend $\left(>2 \mathrm{~mm} \mathrm{a}^{-1}\right)$ since 1979 (Fig. 10), which may result from the strengthening westerlies (e.g. Yao and others, 2012). The background of climate change in recent decades suggests that the increased snow accumulation and summer melt both contribute to WKM glacier changes. Thus, the determination of glacier sensitivity to climate change is essential to understand the slight glacier reduction in the WKM.

The difference in the sensitivity of glaciers to climate change can result in varying glacier response. WKM glaciers are reported to be more sensitive to changes in winter precipitation, rather than temperature variability, in contrast to other regions of the Tibetan Plateau (Kapnick and others, 2014). Furthermore, the increased air temperature in winter will not result in increased melt or changes in precipitation 


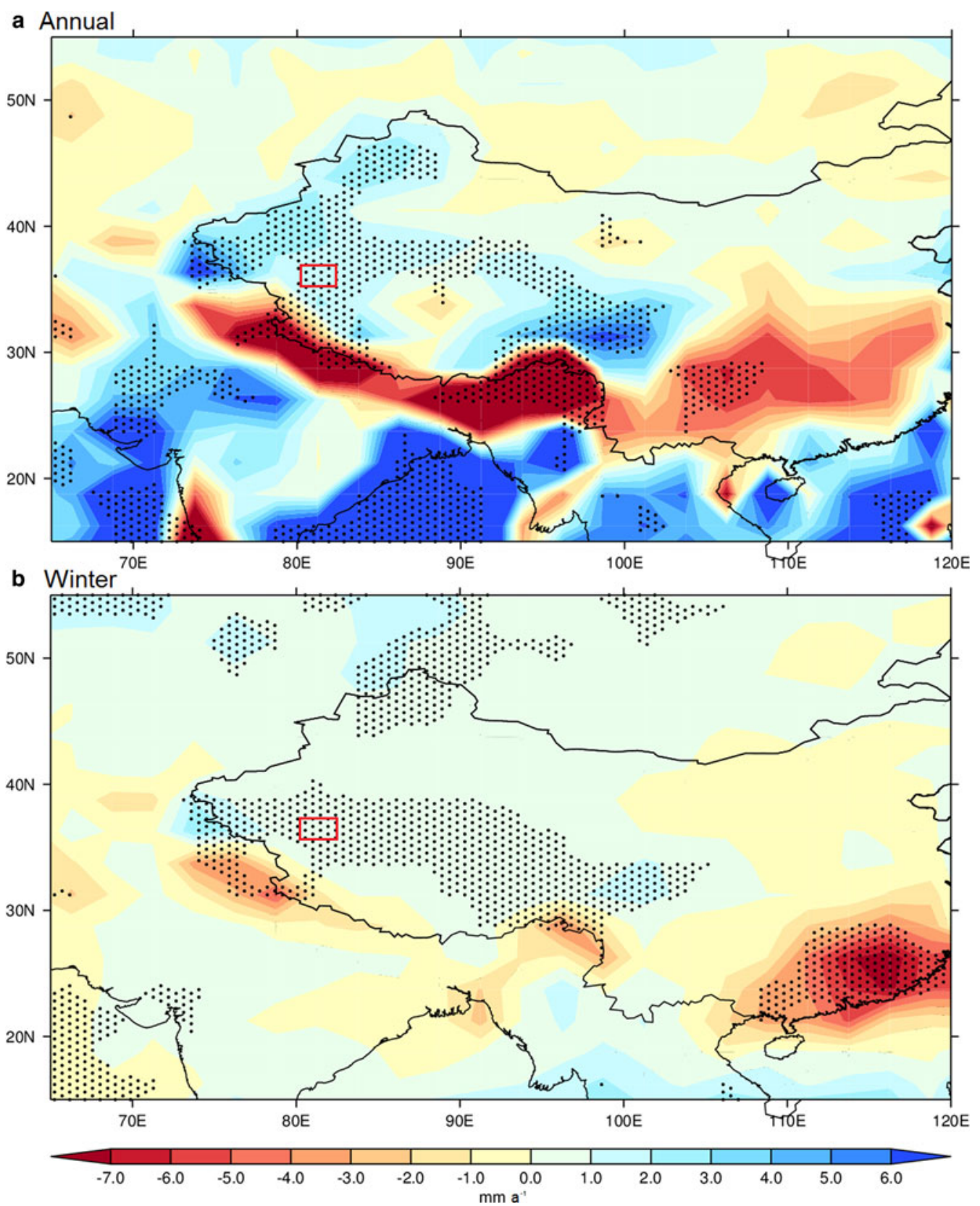

Fig. 10. Linear trend of winter and annual precipitation during the period 1979-2014 from GPCP. Dotted areas denote trends that are statistically above $95 \%$ confidence level. Highlighted box shows the location of WKM.

phase, due to their relatively high altitudes. Thus, the increased winter precipitation likely translates into greater snow accumulation that may offset recent summer warming and ablation season increase in melt on the glacier summer melting over the WKM. Alternatively, de Kok and others (2018) have suggested that intensive regional irrigation leads to increased cloudiness in summer that would reduce ablation. Further research is required to evaluate these two theories.

\section{CONCLUSIONS}

Based on a set of remote-sensing data that includes topographical maps, SRTM DEM and Landsat images, changes in glaciers over the WKM are determined. The analysis of the glacier area change reveals insignificant shrinkage $\left(-0.07 \pm 0.1 \% \mathrm{a}^{-1}\right)$ between the 1970s and 2016, agreeing well with the recent glacier area change estimates by Ji and others (2013) and Bao and others (2015). The slight reduction in glacier extent may imply that the mass budgets in the WKM were also balanced over the last 40 years. However, glacier extent or length changes can only provide an indirect and delayed response to climate change. Here, based on geodetic measurements, we report that WKM glaciers do not experience significant mass change from 1970s to 1999. Combined with mass-balance calculations from ICESat laser altimetry measurements (e.g. Gardner and others, 2013; Kääb and others, 2015), WKM glacier stability is not a recent phenomenon, but has persisted for at least 40 years. The slight reduction in the WKM glaciers may be associated with peculiarities of the regional meteorological or climatic features. More accumulation from increased winter precipitation partly offsets the glacier mass wasting resulting from significant warming during 1970-99. A slowdown in 
warming since 2000 happened in this region and may also be responsible for the nearly balanced mass budgets, even mass gaining, especially for the early 21 st century.

Recently, glaciers in the eastern Pamir and the Hunza catchment in the Karakoram are also reported to have been in balance since the 1970s (Holzer and others, 2015; Bolch and others, 2017; Zhang and others, 2016). These results seem to suggest that the Pamir-Karakoram-WKM glacier anomaly may extend back at least to the 1970s.

\section{SUPPLEMENTARY MATERIAL}

The supplementary material for this article can be found at https://doi.org/10.1017/jog.2018.53

\section{ACKNOWLEDGEMENTS}

This work was supported by the Outstanding Youth Fund of Shandong Provincial Universities (ZR2016JL030), the National Natural Science Foundation of China (41330526 and 41576182), the Chinese Academy of Sciences (XDA19070103, XDB03030101-4) and the National Key Basic Research Program of China (2013CBA01804). We thank the two anonymous reviewers and Joseph Shea (Scientific Editor) for their work, and their comments and suggestions to improve this paper. Thanks to the USGS which provides SRTM DEM and Landsat 8 OLI satellite imagery, GLCF which provides the orthorectified Landsat MSS and TM/ETM+ images, and National Meteorological Information Center, China Meteorological Administration, which provides meteorological data. ICESat data are derived from NSIDC.

\section{REFERENCES}

An W and 6 others (2016) Possible recent warming hiatus on the northwestern Tibetan Plateau derived from ice core records Sci. Rep., 6, 32813 (doi: 10.1038/srep32813)

Bao W, Liu S, Wei J and Guo W (2015) Glacier changes during the past 40 years in the West Kunlun Shan. J. Mount. Sci., 12, 344 357 (doi: 10.1007/s11629-014-3220-0)

Barundun $M$ and 8 others (2015) Re-analysis of seasonal mass balance at Abramov glacier 1968-2014. J. Glaciol., 61, 11031117 (doi: 10.3189/2015JoG14J239)

Beaulieu A and Clavet D (2009) Accuracy assessment of Canadian digital elevation data using ICESat. Photogramm. Eng. Remote Sens., 75, 81-86

Berthier E, Arnaud Y, Vincent C and Rémy F (2006) Biases of SRTM in high-mountain areas: implications for the monitoring of glacier volume changes. Geophys. Res. Lett., 33, L08502 (doi: 10.1029/ 2006GL025862)

Bhambri R and 5 others (2013) Heterogeneity in glacier response in the upper Shyok valley, northeast Karakoram. Cryosphere, 7, 1385-1398

Bolch T and 7 others (2010) A glacier inventory for the western Nyainqentanglha Range and the Nam Co Basin, Tibet, and glacier changes 1976-2009. Cryosphere, 4, 419-433 (doi: 10.5194/tc-4-419-2010)

Bolch T, Pieczonka T and Benn D (2011) Multi-decadal mass loss of glaciers in the Everest area (Nepal Himalayas) derived from stereo imagery. Cryosphere, 5, 349-358

Bolch T and 11 others (2012) The state and fate of Himalayan glaciers. Science, 366, 310-314

Bolch T, Pieczonka T, Mukherjee K and Shea J (2017) Brief communication: Glaciers in the Hunza catchment (Karakoram) have been nearly in balance since the 1970s. Cryosphere, 11, 531539 (doi: 10.5194/tc-11-531-2017)
Citterio $M$ and 6 others (2007) The fluctuations of Italian glaciers during the last century: a contribution to knowledge about Alpine glacier changes. Geogr. Ann. A, 89, 164-182

Citterio M, Paul F, Ahlstrøm AP, Jepsen HF and Weidick A (2009) Remote sensing of glacier change in West Greenland: accounting for the occurrence of surge-type glaciers. Ann. Glaciol., 50, 70-80

Cogley JG (2016) Glaicer shrinkage across High Mountain Asia. Ann. Glaciol., 57, 41-49 (doi: 10.3189/2016AoG71A040)

Copland L and 7 others (2011) Expanded and recently increased glacier surging in the Karakoram. Arct. Antarct. Alp. Res., 43, 503-516 (doi: 10.1657/1938-10 4246-43.4.503)

de Kok RJ, Tuinenburg OA, Bonekamp PNJ and Immerzeel WW (2018) Irrigation as a potential driver for anomalous glacier behavior in High Mountain Asia. Geophys. Res. Lett., 45, 2047-2054 (doi: 10.1002/2017GL076158)

Fischer M, Huss M and Hoelzle M (2015) Surface elevation and mass changes of all Swiss glaciers 1980-2010. Cryosphere, 9, 525-540 (doi: 10.5194/tc-9-525-2015)

Forsythe N, Fowler HJ, Li XF, Blenkinsop S and Pritchard D (2017) Karakoram temperature and glacial melt driven by regional atmospheric circulation variability. Nat. Clim. Change, 7, 664670 (doi: 10.1038/nclimate3361)

Gao YJ and Zang DF (2009) The conversion method and accuracy analysis between WGS-84 coordinate system and $\mathrm{Xi}^{\prime}$ an 80 coordinate system. Eng. surveying mapping, 18, 55-57

Gardelle J, Berthier E and Arnaud Y (2012a) Slight mass gain of Karakoram glaciers in the early 21 st century. Nat. Geosci., 5, 322-325

Gardelle J, Berthier E and Arnaud Y (2012b) Impact of resolution and radar penetration on glacier elevation changes computed from DEM differencing. J. Glaciol., 58, 419-422 (doi: 10.3189/ 2012JoG11J175)

Gardelle J, Berthier E, Arnaud Y and Kääb A (2013) Region-wide glacier mass balances over the Pamir-Karakoram-Himalaya during 1999-2011. Cryosphere, 7, 1263-1286 (doi: 10.5194/ tc-7-1263-2013)

Gardner AS and 15 others (2013) A reconciled estimate of glacier contributions to sea level rise: 2003 to 2009. Science, 340, 852-857

General Administration of Quality Supervision Inspection and Quarantine (2008) GB/T12353.1-2008: Compilation Specifications for National Fundamental Scale Maps-Part 1: Compilation Specifications for 1:25000/1:50000/1:100000 Topographic Maps. General Administration of Quality Supervision Inspection and Quarantine, Beijing

Hewitt K (2005) The Karakoram anomaly? Glacier expansion and the "elevation effect". Karakoram Himalaya. Mt. Res. Dev., 25, 332-340

Holzer $\mathrm{N}$ and 5 others (2015) Four decades of glacier variations at Muztagh Ata (eastern Pamir): a multi-sensor study including Hexagon KH-9 and Pléiades data. Cryosphere, 9, 2071-2088 (doi: 10.5194/tc-9-2071-2015)

Huss M (2013) Density assumptions for converting geodetic glacier volume change to mass change. Cryosphere, 7, 877-887 (doi: 10.5194/tc-7-877-2013)

Immerzeel WW, van Beek LPH and Bierkens MFP (2010) Climate change will affect the Asian water towers. Science, 328, 13821385

Jarvis A, Reuter HI, Nelson A and Guevara E (2008) Hole-filled SRTM for the globe Version 4, available from the CGIAR-CSI SRTM 90 m Database (http://srtm.csi.cgiar.org)

Ji P, Guo H and Zhang L (2013) Remote sensing study of glacier dynamic change in West Kunlun Mountains in the past 20 years. Remote Sens. Land Resources, 25, 93-98 (In Chinese)

Kääb A (2008) Glacier volume changes using ASTER satellite stereo and ICESat GLAS laser altimetry, a test study on Edgeøya, Eastern Svalbard. IEEE Tran. Geosci. Remote Sens., 46, 2823-2830

Kääb A, Berthier E, Nuth C, Gardelle J and Arnaud Y (2008) Contrasting patterns of early twenty-first-century glacier mass change in the Himalayas. Nature, 488, 495-498 
Kääb A, Treichler D, Nuth C and Berthier E (2015) Brief communication: contending estimates of 2003-2008 glacier mass balance over the Pamir-Karakoram-Himalaya. Cryosphere, 9, 557-564

Kapnick SB, Delworth TL, Ashfaq M, Malyshev S and Milly PCD (2014) Snowfall less sensitive to warming in Karakoram than in Himalayas due to a unique seasonal cycle. Nat. Geosci., 7, 834-840

Ke LH, Ding XL and Song CQ (2015) Heterogeneous changes of glaciers over the western Kunlun Mountains based on ICESat and Landsat-8 derived glacier inventory. Remote Sens. Environ., 168, 13-23

Lin H, Li G, Cuo L, Hooper A and Ye Q (2017) A decreasing glacier mass balance gradient from the edge of the Upper Tarim Basin to the Karakoram during 2000-2014. Sci. Rep., 7, 612 (doi: 10.1038/s41598-017-07133-8)

Magruder LA, Webb CE, Urban TJ, Silverberg EC and Schutz BE (2007) ICESat altimetry data product verification at white sands space harbor. IEEE Trans. Geosci. Remote Sens., 45, 147-155

Maurer JM, Rupper SB and Schaefer JM (2016) Quantifying ice loss in the eastern Himalayas since 1974 using declassified spy satellite imagery. Cryosphere, 10, 2203-2215

Maussion F and 5 others (2014) Precipitation seasonality and variability over the Tibetan Plateau as resolved by the High Asia Reanalysis. J. Clim., 27, 1910-1927

Minora $U$ and 10 others (2016) Glacier area stability in the Central Karakoram National Park (Pakistan) in 2001-2010: The "Karakoram Anomaly" in the spotlight. Pro. Phys. Geog., 40, $1-32$

Nuth C and Kääb A (2011) Co-registration and bias corrections of satellite elevation data sets for quantifying glacier thickness change. Cryosphere, 5, 271-290

O'Gorman L (1996) Subpixel precision of straight-edged shapes for registration and measurement. IEEE Trans. Pattern Anal. Mach. Intell., 18, 746-751 (doi: 10.1109/34.506796)

Paul F (2008) Calculation of glacier elevation changes with SRTM: is there an elevation dependent bias? J. Glaciol., 54, 945-946 (doi: 10.3189/002214308787779960)

Paul F and Andreassen LM (2009) A new glacier inventory for the Svartisen region, Norway, from Landsat ETM+ data: challenges and change assessment. J. Glaciol., 55, 607-618

Paul F and Haeberli W (2008) Spatial variability of glacier elevation changes in the Swiss Alps obtained from two digital elevation models. Geophys. Res. Lett., 35, L21502 (doi: 10.1029/ 2008GL034718)

Pieczonka T and Bolch T (2015) Region-wide glacier mass budgets and area changes for the Central Tien Shan between 1975 and 1999 using Hexagon KH-9 imagery Global Planet. Change, 128, 1-13 (doi: 10.1016/j.gloplacha.2014.11.014)

Pieczonka T, Bolch T and Buchroithner MF (2011) Generation and evaluation of multi-temporal digital terrain models of the Mt. Everest area from different optical sensors, ISPRS J. Photogram., 66, 927-940

Pieczonka T, Bolch T, Wei J and Liu S (2013) Heterogeneous mass loss of glaciers in the Aksu-Tarim Catchment (Central Tien Shan) revealed by 1976 KH-9 Hexagon and 2009 SPOT-5 stereo imagery. Remote Sens. Environ., 130, 233-244
Ragettli S, Bolch T and Pellicciotti F (2016) Heterogeneous glacier thinning patterns over the last 40 years in Langtang Himalaya. Cryosphere, 10, 2075-2097

Scherler D, Bookhagen B and Strecker MR (2011) Spatially variable response of Himalayan glaciers to climate change affected by debris cover. Nat. Geosci., 4, 156-159

Shangguan D and 8 others (2007) Glacier changes in the west Kunlun Shan from 1970 to 2001 derived from Landsat TM/ETM+ and Chinese glacier inventory data. Ann. Glaciol., 46, 204-208

Shi Y, Liu S, Ye B, Liu C and Wang Z (2008) Concise glacier inventory of China. Shanghai Popular Science Press, Shanghai, China

Shi Y, Liu C and Kang E (2010) The glacier inventory of China. Ann. Glaciol., 50, 1-4

Smiraglia C and 5 others (2007) Ongoing variations of Himalayan and Karakoram glaciers as witnesses of global changes: recent studies on selected glaciers. Earth Surface Pro., 10, 235-247

Vaughan D and 13 others (2013) Observations: cryosphere. In Stocker T, Qin D, Plattner G-K, Tignor M, Allen S, Boschung J, Nauels A, Xia Y, Bex V and Midgley P, eds. Climate change 2013: the physical science basis, contribution of working group I to the fifth assessment report of the intergovernmental panel on climate change. Cambridge University Press, Cambridge, UK and New York, NY, USA, 317-382

Vögtle T and Schilling KJ (1999) Digitizing maps, In: Bähr H-P and Vögtle T, eds. GIS for environmental monitoring. Schweizerbart, Stuttgart, Germany, 201-216

Wei JF and 6 others (2014) Surface-area changes of glaciers in the Tibetan Plateau interior area since the 1970s using recent Landsat images and historical maps. Ann. Glaciol., 55, 213-222

Wiltshire AJ (2014) Climate change implications for the glaciers of the Hindu Kush, Karakoram and Himalayan region. Cryosphere, 8, 941-958

Yao T and 14 others (2012) Different glacier status with atmospheric circulations in Tibetan Plateau and surroundings. Nat. Clim. Change, 2, 663-667

Yasuda T and Furuya M (2013) Short-term glacier velocity changes at west Kunlun Shan, northwest Tibet, detected by synthetic aperture radar data. Remote Sens. Environ., 128, 87-106

Yasuda T and Furuya M (2015) Dynamics of surge-type glaciers in West Kunlun Shan, Northwestern Tibet. J. Geophys. Res. Earth Surf., 120, 2393-2405 (doi: 10.1002/2015JF003511)

Zhang Z and Jiao K (1987) Modern glaciers on the south slope of West Kunlun Mountains (in Aksayqin Lake and Guozha Co Lake drainage areas). Bull. Glacier Res., 5, 85-91

Zhang W, An R, Yang H and Jiao K (1989) Conditions of glacier development and some glacial features in the West Kunlun Mountains. Bull. Glacier Res., 7, 49-58

Zhang Z and 6 others (2016) Mass change of glaciers in Muztag AtaKongur Tagh, Eastern Pamir, China from 1971/76 to 2013/14 as derived from remote sensing data. PLOS ONE, 11, e0147327 (doi: 10.1371/journal.pone.0147327)

Zhou J, Li Z and Guo W (2014) Estimation and analysis of the surface velocity field of mountain glaciers in Muztag Ata using satellite SAR data. Environ. Earth Sci., 71, 3581-3592

Zhou Y, Li Z, Li J, Zhao R and Ding X (2018) Glacier mass balance in the Qinghai-Tibet Plateau and its surroundings from the mid1970s to 2000 based on Hexagon KH-9 and SRTM DEMs. Remote Sens. Environ., 210, 96-112 